J. Am e R. So c. Hort. Sci. 120(5):848-853. 1995.

\title{
Soil Temperature and Tomato Growth Associated with Black Polyethylene and Hairy Vetch Mulches
}

\author{
John R. Teasdale ${ }^{1}$ and Aref A. Abdul-Baki ${ }^{2}$ \\ U.S. Department of Agriculture-Agricultural Research Service, Beltsville, MD 20705 \\ Additional index words. Lycopersicon esculentum, Vicia villosa, cover crop, raised bed, root length
}

\begin{abstract}
Temperature and root length at selected locations within a raised bed under black polyethylene, hairy vetch (Vicia villosa Roth) residue, or bare soil were measured and correlated with tomato (Lycopersicon esculentum Mill.) growth. Early in the season, before the tomato leaf canopy closed, soil temperature was influenced more by vertical depth in the bed than by horizontal position across the bed. Maximum soil temperatures under black polyethylene averaged 5.7 and 3.4C greater than those under hairy vetch at 5 and $15 \mathrm{~cm}$ deep, respectively. More hours at optimum temperatures for root growth (20 to $30 \mathrm{C}$ ) during the first 4 weeks of the season probably accounted for greater early root and shoot growth and greater early yield of tomatoes grown with black polyethylene than hairy vetch residue or bare soil. After canopy closure, soil temperatures under tomato foliage within the row were reduced by an average of 5.2 and $2.2 \mathrm{C}$ at 5 and $15 \mathrm{~cm}$ deep, respectively, compared to those on the outer edge of the beds. Most tomato roots were in areas of the bed covered by the tomato canopy where temperatures in all treatments remained in the optimum 20 to $30 \mathrm{C}$ range almost continuously. Soil temperature, therefore, did not explain why tomato plants in the hairy vetch treatment had equal or higher total yields than the black polyethylene or unmulched treatments.
\end{abstract}

Mulches are well-known for modifying the energy and water balance at the surface of soils and creating more favorable conditions for plant growth. Mulches conserve soil moisture by retarding evaporation (Hillel, 1982), but effects on soil temperature vary depending on the composition and optical properties of the mulch (Ham et al., 1993). In general, polyethylene mulches raise maximum and minimum soil temperatures relative to unmulched soil (Ashworth and Harrison, 1983; Ham et al., 1993; Liakatas et al., 1986), whereas, organic mulches decrease maximum but increase minimum soil temperature (Ashworth and Harrison, 1983; Bristow, 1988; Teasdale and Mohler, 1993).

Hairy vetch is a winter annual legume that has been successfully used as a cover crop for fresh-market tomato production on raised beds with trickle irrigation (Abdul-Baki and Teasdale, 1993). After being seeded on beds in the fall, hairy vetch produces abundant biomass by the time of tomato planting in the spring. The dense growth of vines produces an organic mulch on the surface of the beds when mowed. After mowing, tomato seedlings are transplanted without tillage through this mulch. Total yields are higher in this hairy vetch cover-crop system than in a conventional system with black polyethylene mulch or bare soil (Abdul-Baki and Teasdale, 1993).

Soil temperature would be expected to respond differentially to black polyethylene and hairy vetch mulches. There is a need to understand the extent of temperature differences throughout the raised bed to understand the impact of these mulches on tomato growth. Therefore, this research was conducted to 1) determine soil temperatures at selected locations within the bed profile throughout the growing season under a black polyethylene or hairy vetch mulch and 2) assess the pattern of root growth within the bed profile so associations between soil temperature and plant growth could be determined.

Received for publication 8 Sept. 1994. Accepted for publication 23 Feb. 1995. The cost of publishing this paper was defrayed in part by the payment of page charges. Under postal regulations, this paper therefore must be hereby marked advertisement solely to indicate this fact.

'Plant physiologist, Weed Science Laboratory.

*Plant physiologist, Vegetable Laboratory.

\section{Materials and Methods}

Field experiments were conducted in 1992 and 1993 on a Keyport fine sandy loam (clayey, mixed, mesic, Aquic Hapludult) at the Beltsville Agricultural Research Center North Farm, Beltsville, Md. Beds $1.5 \mathrm{~cm}$ high and $0.9 \mathrm{~m}$ wide and spaced $1.5 \mathrm{~m}$ center to center were prepared in a north-south direction. Tomato plants were grown in flats in the greenhouse for 4 weeks, hardened in a cold frame for 1 week, and transplanted in the center of beds on 13 May 1992 and 11 May 1993. 'Sunny' was grown at 60-cm intervals within row in 1992 and 'Sunbeam' at $55-\mathrm{cm}$ intervals in 1993. Transplanting was performed by hand in 1992 and with anotillage, punch-type planter (Holland Co., Holland, Mich.) in 1993. Stakes were inserted between every other plant and foliage was tied up with three layers of string woven between stakes. Weeds were controlled successfully with postemergence applications of $0.56 \mathrm{~kg} \cdot \mathrm{ha}^{-1}$ of 4-amino-6-(1,1-dimethylethyl)-3-(methylthio)1,2,4-triazin-5(4H)-one (metribuzin) and $0.2 \mathrm{~kg} \cdot \mathrm{ha}^{-1}$ of 2-[1(ethoxyimino)bufyl]-5-[2-(ethylthio)propyl]-3-hydroxy-2cyclohexen-1-one (sethoxydim). Recommendations from a local integrated pest management program were followed for controlling insects and diseases.

Three mulch treatments were compared: none, black polyethylene, and hairy vetch. Beds for the no-mulch and black-polyethylene treatments were prepared in the spring before transplanting. One trickle-irrigation line (Turbo Tape, Zimmerman Irrigation, Mifflingburg, Pa.) $(0.25 \mathrm{~mm}$ thick, $30 \mathrm{~cm}$ emitter spacing, 350 liters.ha ${ }^{-1}$ discharge rate $/ 100-\mathrm{m}$ line) was buried $3 \mathrm{~cm}$ below the surface of each bed and $8 \mathrm{~cm}$ west of the tomato rows. A nondegradable, black-embossed polyethylene film $1.2 \mathrm{~m}$ wide and 0.025 $\mathrm{mm}$ thick (Leco Industries, Montreal, Canada) was laid mechanically over the raised beds designated for that treatment.

Beds for the hairy vetch treatment were prepared and seeded in September before each experiment. The hairy vetch vines were flail-mowed 1 day before transplanting leaving a finely chopped layer of residue that dried within a few days. The resulting mulch; was about $5 \mathrm{~cm}$ thick and had a dry weight of 4950 and 4360 $\mathrm{kg} \cdot \mathrm{ha}^{-1}$ in 1992 and 1993, respectively. Tomato seedlings were transplanted into beds with minimal disruption of the mulch. Drip irrigation lines were secured on the surface of the mulch $8 \mathrm{~cm}$ west 
of the tomato rows. The metribuzin application about 3 weeks after mowing terminated vetch regrowth and emerging weeds.

Soil tests in 1992 revealed very high levels of $\mathrm{P}$ and high levels of K. Nutrients were applied to the bare soil and black polyethylene treatments in 15 weekly applications through the trickle-irrigation system. Total nutrients applied were $112 \mathrm{~kg}$ of N, $8 \mathrm{~kg}$ of P, and 35 $\mathrm{kg}$ of K/ha of bed area. Soil tests in 1993 revealed very high levels of $\mathrm{P}$ and $\mathrm{K}$. Consequently, only $\mathrm{N}$ was applied to the bare soil and black polyethylene treatments in 14 weekly applications through the trickleirrigation system providing a total of $112 \mathrm{~kg}$ of N/ha of bed area. The hairy vetch treatment in both years received the same number of irrigations but half the fertilizer applications described above.

Each treatment was randomly assigned to two 61-m rows in 1992 and four 31-m rows in 1993. Four subplots per treatment consisting of 15 plants were set aside for fruit harvest, and additional sections of row were designated for plant sampling and temperature measurements. Above-ground portions of two representative plants per treatment were removed 4 and 6 weeks after transplanting in 1992 and 1993, respectively, for leaf area and dry weight measurements.

Soil temperature. Soil temperature was measured with 107B thermistors (Campbell Scientific, Logan, Utah) placed between tomato plants where there was no stake 5 or $15 \mathrm{~cm}$ deep and $5 \mathrm{~cm}$ from the west edge of the bed 5 or $15 \mathrm{~cm}$ deep. A screwdriver the same diameter as the thermistor was inserted into the soil at a 45" angle to the soil surface to make a track for insertion of the thermistor. Each mulch-depth-location was replicated two to four times in 1992 and four times in 1993. Variation in replication in 1992 was because thermistors were moved during the season to increase the number of depths and locations sampled.

Soil temperature data were collected with a $21 \mathrm{X}$ datalogger (Campbell Scientific) at 5-min intervals. Average hourly and daily maximum and minimum soil temperatures were saved. Thermistors were connected to the datalogger through two AM416 multiplexers (Campbell Scientific) with the half-bridge completion resistor between the multiplexer and datalogger. The thermistors were wired to the multiplexer so that all treatments in one replication passed through the same multiplexer COM terminal and completion resistor.

Before field installation, all thermistors were placed in a closed container of water so that no contact with the surface of the container was permitted and no direct solar radiation was allowed to enter the container. Standard deviations of measurements from all sensors (including variation due to multiplexer channels) were 0.19 and $0.63 \mathrm{C}$ in 1992 and 1993, respectively. Based on this calibration, an adjustment factor equal to the deviation from the mean was established for each sensor. All data were adjusted by this factor before analysis.

Additional weather data were collected from a station at the edge of the field. Air temperature at a 2-m height was collected at 5-min intervals with a 207 temperature and relative humidity probe (Phys-Chem Scientific Corp., New York) housed in a radiation shield. Solar radiation was collected at 5-sec intervals with a pyranometer (LI-200S; LI-COR, Lincoln, Neb.). Rainfall was collected at 5-sec intervals with a TE525 tipping bucket rain gauge (Texas Electronics, Dallas).

Root length. Soil cores $7.6 \mathrm{~cm}$ in diameter were taken at three locations on the beds: within the row and adjacent to a tomato plant, $20 \mathrm{~cm}$ from the tomato plant toward the west edge of the bed, and $40 \mathrm{~cm}$ from the tomato plant toward the west edge of the bed. At each location, cores were taken in 10-cm increments to a depth of $50 \mathrm{~cm}$ where a hard pan was encountered. Four replications of samples were taken from each mulch treatment. One replication of all treatments was collected each day from 22 to 25 June 1993.

Soil from each mulch-depth-location was sealed in a plastic bag until isolating roots later in the same day. Soil was washed through a 2.4-mm sieve and roots were collected with forceps. Preliminary trials demonstrated that few additional root fragments were collected using sieve sizes of 1.7 or $1.0 \mathrm{~mm}$. Roots were placed on a $2.5-\mathrm{cm}$ grid and length was determined by counting intersections according to the method of Tennant (Böhm, 1979).

\section{Results and Discussion}

During the 2 years of this experiment, contrasting weather conditions were experienced (Fig. 1). Radiation was relatively low and rainfall was relatively high in 1992 compared to 1993. Radiation only exceeded $20 \mathrm{~mJ} \cdot \mathrm{m}^{-2} \cdot$ day $^{-1}$ during 2 weeks in 1992 but exceeded this level during 6 weeks in 1993. There were 7 weeks with $>25 \mathrm{~mm}$ of rain in 1992 , whereas there was only 1 week exceeding this level in 1993. Maximum air temperature followed the same trend as radiation and tended to be higher in 1993 than 1992 (Fig. 2), but minimum air temperature exhibited no clear difference between years (Fig. 3).

Maximum soil temperature. Maximum soil temperature, as illustrated by data from $15 \mathrm{~cm}$ deep within the tomato row, was, with few exceptions, greatest under black polyethylene, least under hairy vetch, and intermediate in bare soil during the first 12 weeks of each year (Fig. 2). Differences between black polyethylene and hairy vetch averaged about 3 to $4 \mathrm{C}$ early in the season. On an individual day with high solar radiation during week 2 of 1992 , maximum soil temperature was $6.6 \mathrm{C}$ higher under black polyethylene than under hairy vetch (Fig. 4).

Higher maximum soil temperatures under black polyethylene have been explained by the optical properties of this mulch (Ham

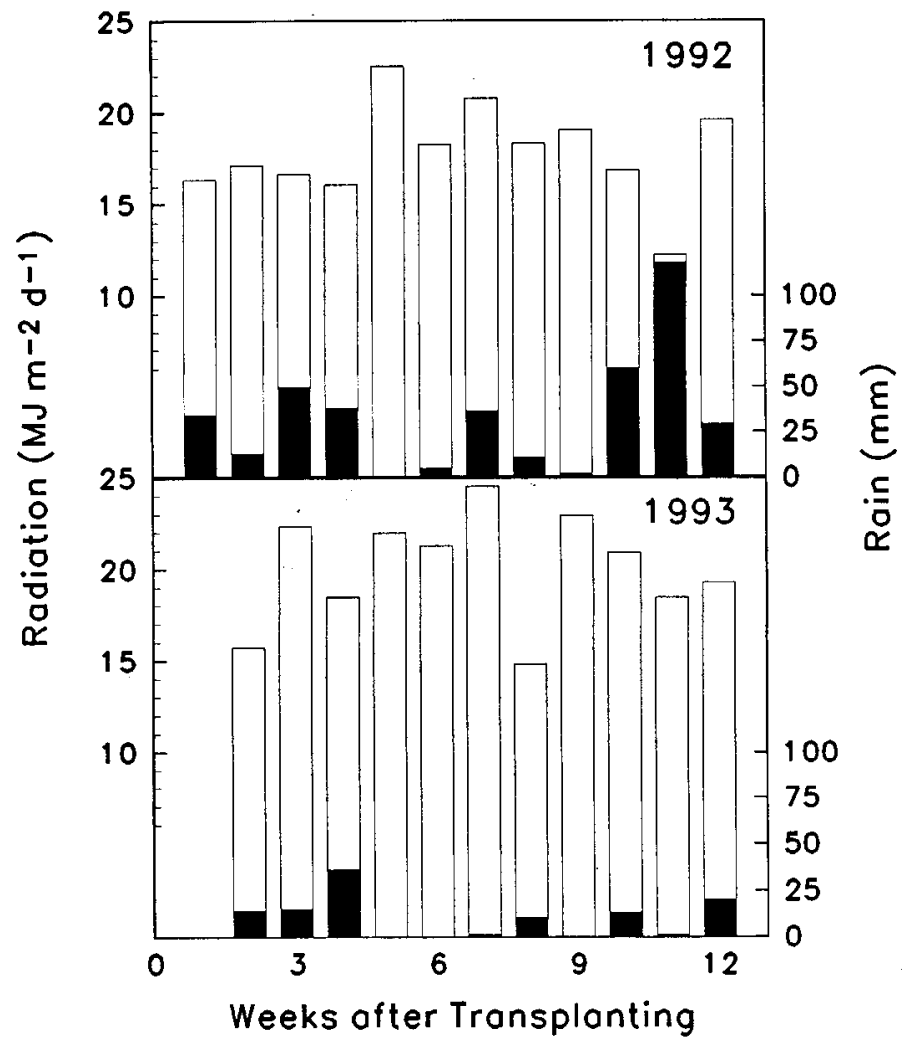

Fig. 1. Radiation (open bars) and rainfall (solid bars) during the first 12 weeks after transplanting in 1992 and 1993. Radiation values are weekly averages and rainfall values are weekly totals. 
et al., 1993; Liakatas et al., 1986). Less than $10 \%$ of shortwave radiation is reflected or transmitted by black polyethylene; the remainder, $>90 \%$, is absorbed. If there is good soil-to-mulch contact, as there was in this experiment, then significant conduction can occur from the mulch to the soil. Little energy is lost through evaporation, resulting in a net gain of soil heat during the day.

Bare soil reflectance can vary depending on moisture content and soil composition, but values of about $20 \%$ are common (Bristow, 1988; Ham et al., 1993; Liakatas et al., 1986). Evaporation of soil moisture also accounts for 3 significant energy loss from bare soil (Bristow, 1988). As a result of greater loss from reflectance and evaporation, bare soil would be expected to store less solar energy as heat than soil under black polyethylene.

Reflectance from an organic mulch is similar to that from bare soil (Bristow, 1988). Radiation not reflected or transmitted would be absorbed by a hairy vetch mulch. This mulch forms a matt of vetch stems with a significant amount of air space within the mulch. Because air has low thermal conductivity (Hillel, 1982), substantially less heat would be conducted from the mulch to the soil than would be conducted by black polyethylene. Therefore, the primary energy for heating the soil would be transmitted radiation. Photosynthetic photon flux density (PPFD) transmittance through hairy vetch residue with a similar biomass to that in this experiment ranged from $14 \%$ to $33 \%$ (Teasdale and Mohler, 1993). Since transmittance was relatively independent of wavelength (Teasdale and Mohler, 1993), transmittance of total short-

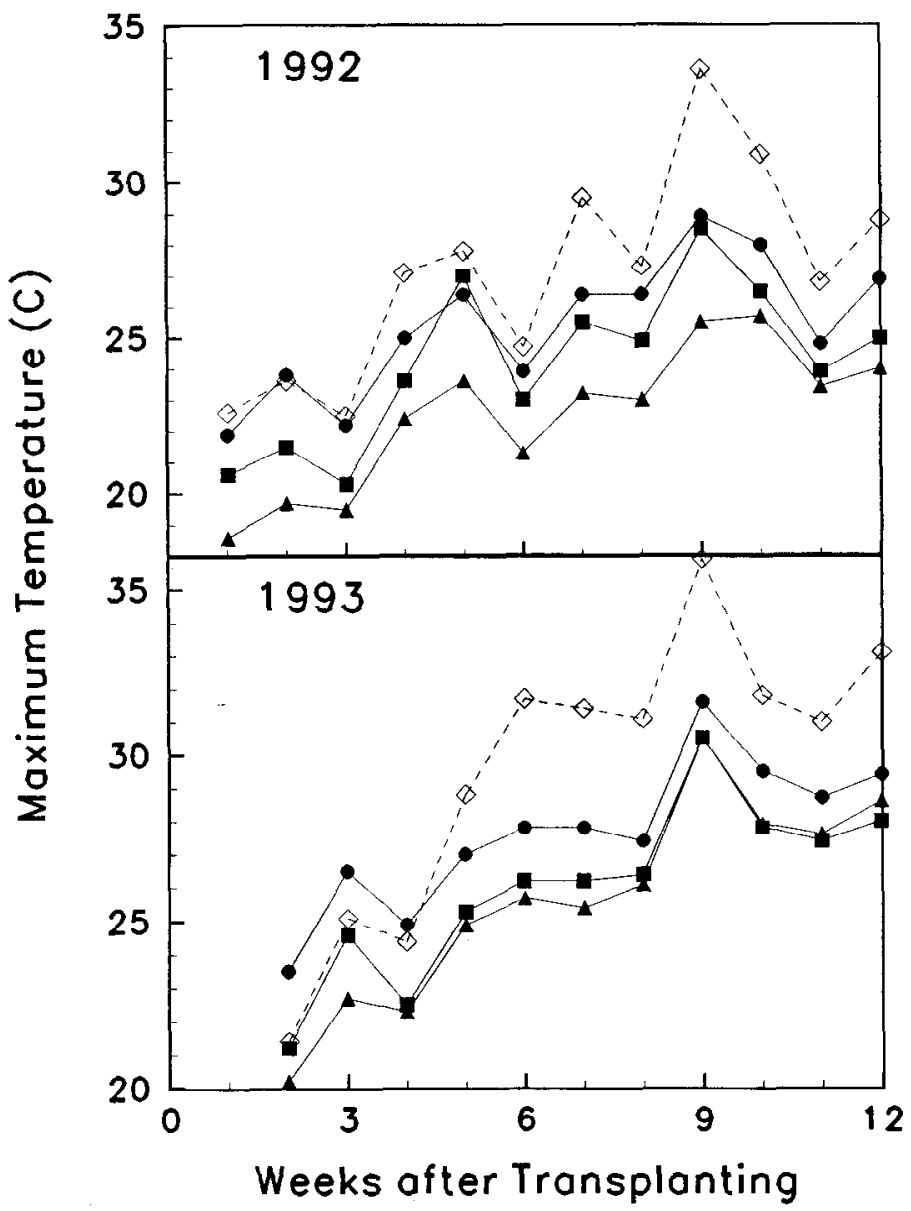

Fig. 2. Maximum soil temperature $15 \mathrm{~cm}$ deep within the tomato row under black polyethylene mulch (solid circles), bare soil (solid squares), and hairy vetch residue (solid triangles) and maximum air temperature (open diamonds) during the first 12 weeks after transplanting. Values are weekly means. The average weekly LSD $(\mathrm{P}=0.05)$ equalled 1.2 and $1.0 \mathrm{C}$ in 1992 and 1993 , respectively. wave radiation would be similar to that for PPFD. This substantial reduction in transmittance accounts for lower soil temperature under hairy vetch compared to bare soil.

The pattern of maximum soil temperature within the bed profile changed as the season progressed. For convenience of presentation, data from each year were divided into three phases exhibiting different patterns of response (Tables 1 and 2). The first phase was characterized by relatively unshaded beds during early tomato plant development. There were greater differences between maximum temperatures due to depth than bed location (Table 2). Maximum temperature under black polyethylene averaged 5.7C greater than that under hairy vetch at $5 \mathrm{~cm}$ deep and $3.4 \mathrm{C}$ greater at $15 \mathrm{~cm}$ deep in 1993.

The second phase was characterized by the tomato leaf canopy closing over the row. As a result of intercepted radiation by the canopy,. soil temperatures were lower in the middles than on the edges of the beds (Table 2). This effect was most dramatic at $5 \mathrm{~cm}$ deep where soil temperatures averaged 5.3C warmer at the edges than at the center of the beds. The temperature difference between the black polyethylene and hairy vetch treatments was less during the second than first phase because of decomposition of the hairy vetch mulch. Hairy vetch residue loses about half of its biomass by the second month of the season (Teasdale and Daughtry, 1993). Temperature differences between the hairy vetch and bare-soil treatment were greater during the second phase in 1992 than 1993 because poor tomato growth in the bare-soil treatment left some

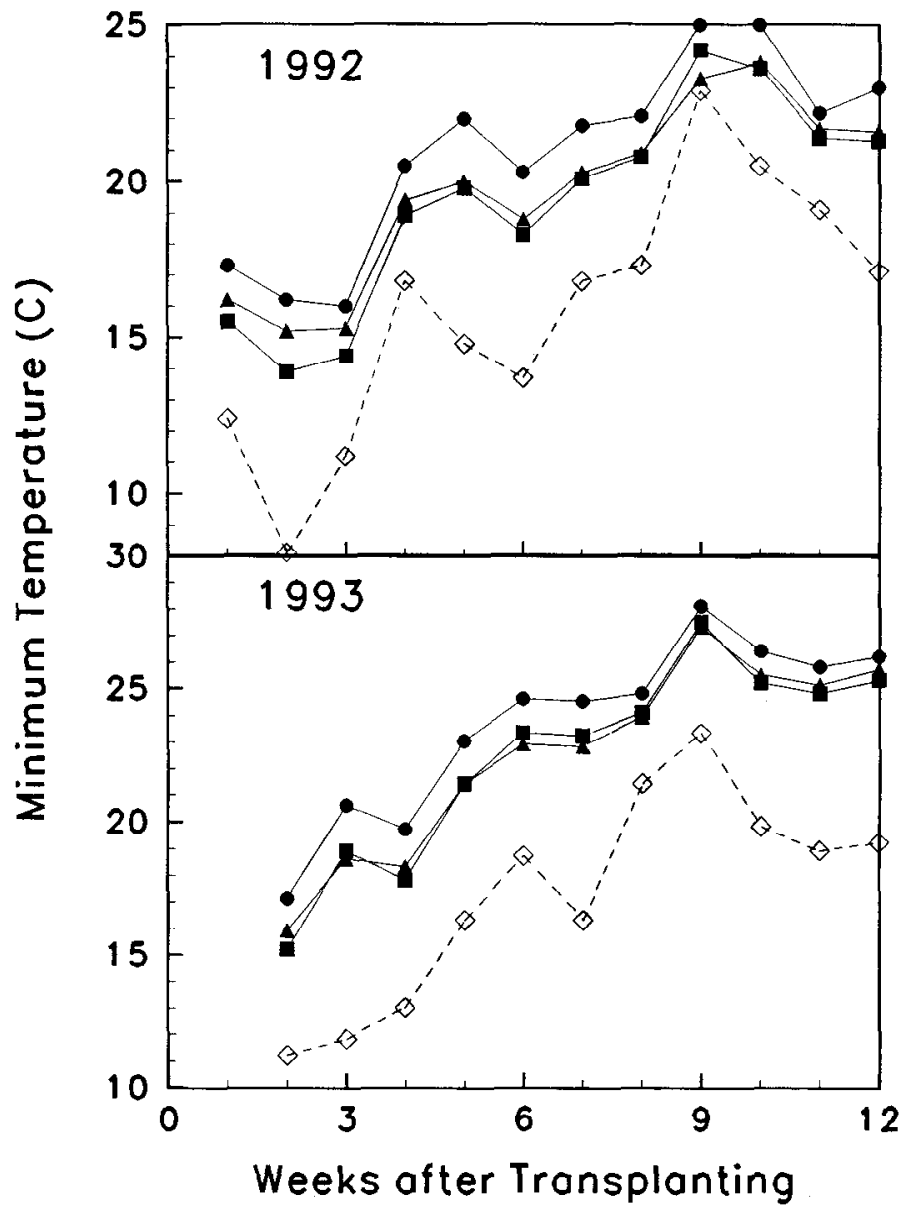

Fig. 3. Minimum soil temperature $15 \mathrm{~cm}$ deep within the tomato row under blaik polyethylene mulch (solid circles), bare soil (solid squares), and hairy vetch residue (solid triangles) and minimum air temperature (open diamonds) during the first 12 weeks after transplanting. Values are weekly means. The average weekly LSD $(\mathrm{P}=0.05)$ equalled $0.4 \mathrm{C}$ in 1992 and 1993. 


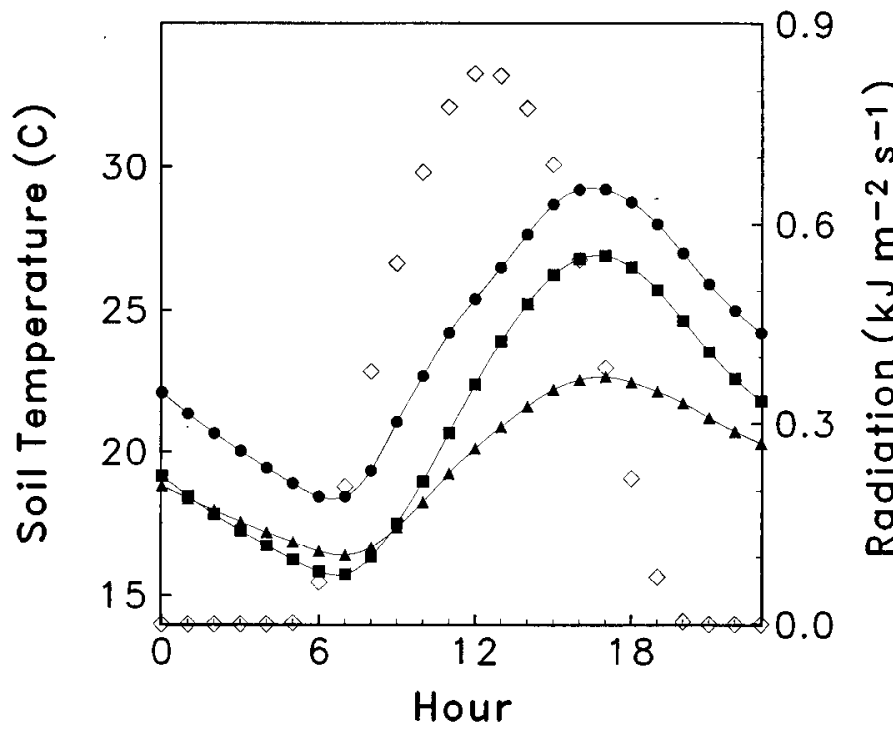

Fig. 4. Soil temperature $15 \mathrm{~cm}$ deep within the tomato row under black polyethylene mulch (solid circles), bare soil (solid squares), and hairy vetch residue (solid triangles) and solar radiation (open diamonds) during day 144 (10 days after transplanting) of 1992. Values are means of measurements during the preceding hour. Hours refer to eastern standard time. Total radiation received on this day was $25142 \mathrm{~kJ} \cdot \mathrm{m}^{-2}$, maximum air temperature was $31.8 \mathrm{C}$, and minimum air temperature was $10.5 \mathrm{C}$.

sites within row exposed to direct radiation in 1992.

The third phase of the season was characterized by further decomposition of the hairy vetch mulch. By this time, transmittance through vetch residue can reach levels up to $92 \%$ (Teasdale and Mohler, 1993). In addition, the remaining vetch residue became compressed against the soil, losing the insulating value that previously existed. As a result, there was very little difference between the bare-soil and hairy vetch treatments during this phase of the season (Tables 1 and 2).

A major difference in response to mulches was evident between
1992 and 1993 at the 5-cm, bed-edge location (Tables 1 and 2). The large temperature difference between the black polyethylene and hairy vetch treatments that was seen early in the season at this bed location was still evident during the last phase of the season in 1992 but not in 1993. This difference in response can be explained by different rainfall patterns during 1992 and 1993. The weather in 1992 was characterized by relatively consistent rainfall throughout the season and particularly high rainfall during weeks 10 to 12 , whereas 1993 was characterized by drought beginning week 5 and intensifying during weeks 8 to 12 (Fig. 1). A total of $25 \mathrm{~mm}$ of rain fell in small increments during this 8-week period before $20 \mathrm{~mm}$ of rain fell on the second to last day of week 12. During this drought, the upper shoulders of the bare-soil and hairy vetch beds dried despite drip irrigation in the center of the bed. Under these conditions, very little energy would be lost from evaporation with a resulting increase in soil heat (Bristow, 1988). This accounts for the similar soil temperatures among mulch treatments at the $5-\mathrm{cm}$, bed-edge location in 1993 during weeks 8 to 12 . After the $20-\mathrm{mm}$ rainfall during week 12 of 1993 , evaporation of soil moisture allowed the soil to cool sufficiently under the bare soil and hairy vetch so that these treatments averaged $2.2 \mathrm{C}$ cooler than soil under black polyethylene (Table 3).

Minimum soil temperature. Minimum soil temperatures under black polyethylene were consistently 1 to $2 \mathrm{C}$ greater than those under hairy vetch, as illustrated by data from the $15-\mathrm{cm}$, in-row location (Fig. 3). Minimum soil temperatures under hairy vetch were slightly higher than those under bare soil during the early part of the season but were similar during the later part of the season. Greater heat storage under black polyethylene during the day could account, in part, for higher minimum soil temperatures under black polyethylene mulch at night. In addition, both mulches probably lost less energy from soils at night than bare soil by limiting losses from evaporation and long-wave radiation (Ham et al., 1993; Liakatas et al., 1986). Minimum soil temperatures of all mulch treatments were slightly lower at 5 than $15 \mathrm{~cm}$ deep and at the edge than middle of the bed (data not shown).

Table 1. Maximum soil temperatures at selected locations within the bed during the 1992 experiment. Values are the average of maximum soil temperatures over the period specified.

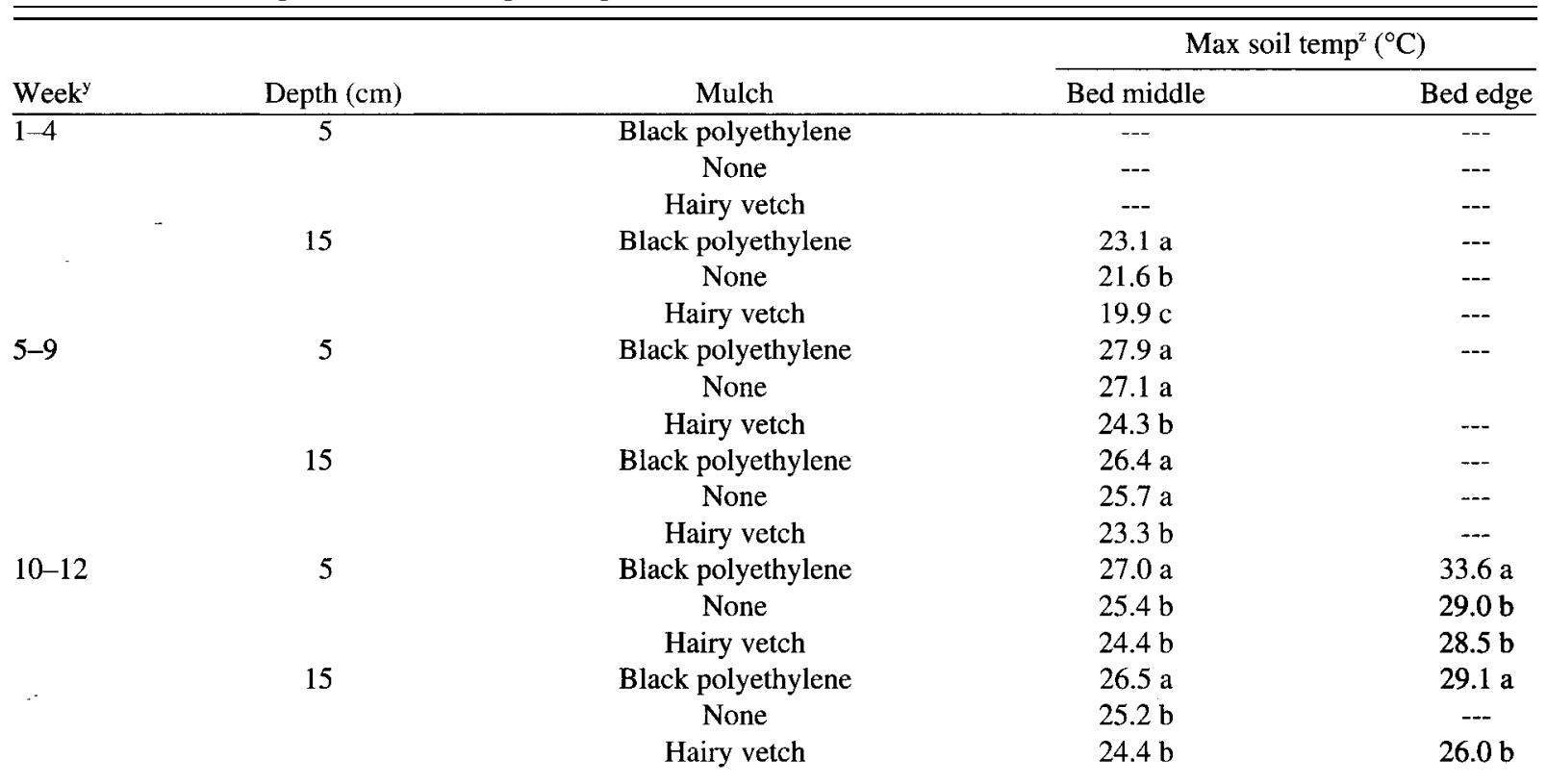

${ }^{7}$ Values within time, depth, and location followed by the same letter are not significantly different according to Fisher's LSD $(P=0.05)$. 'Weeks 1-4 were characterized by relatively unshaded beds, weeks 5-9 by canopy closure over the row, and weeks 10-12 by hairy vetch decomposition. 
Table 2. Maximum soil temperatures at selected locations within the bed during the 1993 experiment. Values are the average of maximum soil temperatures over the period specified.

\begin{tabular}{|c|c|c|c|c|}
\hline \multirow[b]{2}{*}{ Week $^{y}$} & \multirow[b]{2}{*}{ Depth (cm) } & \multirow[b]{2}{*}{ Mulch } & \multicolumn{2}{|c|}{ Max soil temp ${ }^{z}\left({ }^{\circ} \mathrm{C}\right)$} \\
\hline & & & Bed middle & Bed edge \\
\hline \multirow[t]{6}{*}{$2-3$} & 5 & Black polyethylene & $28.4 \mathrm{a}$ & $30.0 \mathrm{a}$ \\
\hline & & None & $27.5 \mathrm{~b}$ & $27.7 \mathrm{~b}$ \\
\hline & & Hairy vetch & $23.0 \mathrm{c}$ & $24.1 \mathrm{c}$ \\
\hline & 15 & Black polyethylene & $25.0 \mathrm{a}$ & $25.1 \mathrm{a}$ \\
\hline & & None & $22.9 \mathrm{~b}$ & $23.6 \mathrm{~b}$ \\
\hline & & Hairy vetch & $21.5 \mathrm{c}$ & $21.8 \mathrm{c}$ \\
\hline \multirow[t]{6}{*}{$4-7$} & 5 & Black polyethylene & $28.4 \mathrm{a}$ & $34.2 \mathrm{a}$ \\
\hline & & None & $27.0 \mathrm{~b}$ & $32.3 \mathrm{~b}$ \\
\hline & & Hairy vetch & $25.5 \mathrm{c}$ & $30.4 \mathrm{c}$ \\
\hline & 15 & Black polyethylene & $26.9 \mathrm{a}$ & $29.2 \mathrm{a}$ \\
\hline & & None & $25.1 \mathrm{~b}$ & $27.5 \mathrm{~b}$ \\
\hline & & Hairy vetch & $24.6 \mathrm{~b}$ & $27.2 \mathrm{~b}$ \\
\hline \multirow[t]{6}{*}{$8-12$} & 5 & Black polyethylene & $29.9 \mathrm{a}$ & $34.5 \mathrm{a}$ \\
\hline & & None & $28.5 \mathrm{~b}$ & $34.1 \mathrm{a}$ \\
\hline & & Hairy vetch & $28.2 \mathrm{~b}$ & $34.3 \mathrm{a}$ \\
\hline & 15 & Black polyethylene & $29.3 \mathrm{a}$ & $31.2 \mathrm{a}$ \\
\hline & & None & $28.0 \mathrm{~b}$. & $29.8 \mathrm{~b}$ \\
\hline & & Hairy vetch & $28.2 \mathrm{~b}$ & $30.9 \mathrm{a}$ \\
\hline
\end{tabular}

${ }^{2}$ Values within time, depth, and location followed by the same letter are not significantly different according to Fisher's LSD ( $\left.\mathrm{P}=0.05\right)$.

${ }^{y}$ Weeks 2-3 were characterized by relatively unshaded beds. weeks 4-7 by canopy closure over the row, and weeks $8-12$ by hairy

vetch decomposition.

Tomato growth. Most tomato root length was in the upper $30 \mathrm{~cm}$ of the bed, with only $12 \%$ below this level (Table 4). Aside from the high density of primarily structural roots adjacent to the plant, roots were distributed relatively uniformly throughout the upper $30 \mathrm{~cm}$ of the bed. Lower densities of roots extended beyond $30 \mathrm{~cm}$ to a hard pan at 40 to $50 \mathrm{~cm}$ deep. Others have reported significant tomato root growth to depths below the upper $30 \mathrm{~cm}$ in bare soil (Weaver and Bruner, 1927) and mulches (Tindall et al., 1991). Knave1 and Mohr (1967) observed greater horizontal and shallower vertical root growth of tomato under black polyethylene than unmulched soil. However, the research by Knave1 and Mohr (1967) used an in situ excavation approach that probably did not accurately measure finer roots at greater depths. We found no significant interaction between mulch and either bed location or depth.

Optimum root temperature for mineral uptake and tomato growth is about 25C (Maletta and Janes, 1987; Tindall et al., 1990). Quadratic regression models showed that growth of tomato shoots and roots was $>90 \%$ of the maximum when root temperatures were $20 \mathrm{C}$ to $30 \mathrm{C}$ but declined rapidly outside this range (Tindall et al., 1990). Maletta and Janes (1987) showed that rate of plant growth or root elongation was severely limited at a root temperature of $32 \mathrm{C}$.

Soil temperatures below 20C undoubtedly limited tomato growth early in the season in our experiments. During the early weeks of each year, soil temperatures exceeded 20C for only a portion of most days. The relation of soil temperature to tomato growth can be examined by comparing the fraction of each day that soil temperature in each treatment was in the optimum temperature range during the early weeks of the season. Soil temperature at 15 $\mathrm{cm}$ deep within the row was chosen as most representative of conditions encountered by most roots based on root distribution data (Table 4).

During the first 4 weeks of both years, black polyethylene almost doubled the number of hours that soil temperature at $15 \mathrm{~cm}$ deep remained in the optimum temperature range of 20 to $30 \mathrm{C}$ compared to unmulched or hairy vetch treatments (Table 5). Greater length of exposure to optimum root temperatures under black polyethylene mulch probably accounts for increased root and shoot growth in that treatment early in the season. Greater early vegetative growth by tomatoes grown with black polyethylene mulch also led to greater early yield than that in the other treatments. These results support those of Wien et al. (1993), who showed that increased tomato growth and yield by polyethylene mulching is a consequence of enhanced root growth and nutrient uptake early in the season.

Table 3. Maximum soil temperature at $5 \mathrm{~cm}$ deep on the edge of the bed before and after a 20-mm rainfall on day 214 of 1993.

\begin{tabular}{|c|c|c|c|c|}
\hline \multirow[b]{2}{*}{ Variable } & \multirow[b]{2}{*}{ Mulch } & \multicolumn{3}{|c|}{ Day } \\
\hline & & 213 & 214 & 215 \\
\hline Max air temp $\left({ }^{\circ} \mathrm{C}\right)$ & --- & 32.9 & 34.1 & 33.2 \\
\hline Min air temp $\left({ }^{\circ} \mathrm{C}\right)$ & --- & 17.7 & 18.4 & 20.5 \\
\hline Radiation $\left(\mathrm{kJ} \cdot \mathrm{m}^{-2} \cdot \mathrm{s}^{-1}\right)$ & --- & 19872 & 18403 & 17280 \\
\hline Rain (mm) & --- & 0 & $20^{z}$ & 0 \\
\hline \multirow[t]{3}{*}{ Max soil temp ${ }^{y}\left({ }^{\circ} \mathrm{C}\right)$} & Black polyethylene & $33.5 \mathrm{a}$ & $31.6 \mathrm{a}$ & $34.7 \mathrm{a}$ \\
\hline & None & $33.6 \mathrm{a}$ & $32.1 \mathrm{a}$ & $32.5 \mathrm{~b}$ \\
\hline & Hairy vetch & $34.2 \mathrm{a}$ & $32.5 \mathrm{a}$ & $32.5 \mathrm{~b}$ \\
\hline
\end{tabular}

Rainfall occurred between 1400 and $1500 \mathrm{HR}$

'Values within days followed by the same letter are not significantly different according to an $\operatorname{LSD}(\mathrm{P}=0.05)$ : 
Table 4. Tomato root length density at various depths and locations on a cross-sectional profile of the tomato bed 6 weeks after transplanting in 1993. Means are averaged across mulches because there were no significant interactions between depth or location and mulch according to the analysis of variance $\mathrm{F}$ test $(\mathrm{P}=0.05)$.

\begin{tabular}{lccc}
\hline \hline & & $\begin{array}{c}\text { Root length density }\left(\mathrm{cm}^{2} \cdot \mathrm{dm}^{-3}\right) \\
\text { at various distances } \\
\text { from tomato plants }\end{array}$ \\
\cline { 2 - 4 } Depth $(\mathrm{cm})$ & 0 & 20 & 40 \\
\hline $0-10$ & 661 & 363 & 224 \\
$10-20$ & 329 & 256 & 242 \\
$20-30$ & 259 & 212 & 230 \\
$30-40$ & 100 & 109 & 110 \\
$40-50$ & 17 & 14 & 18 \\
LSD $_{(0.05)}$ & & 89 &
\end{tabular}

Distance from tomato plants: $0 \mathrm{~cm}=$ center of bed. $20 \mathrm{~cm}$ = half-way to edge of bed, and $40 \mathrm{~cm}=$ edge of bed. Drip irrigation line was $8 \mathrm{~cm}$ from center of bed.

Most of the bed area in our experiments was covered by the tomato canopy after the third or fourth week of the season. Therefore, most roots in the bed would be subject to temperature conditions similar to those measured within the row. Soil temperatures within the row rarely exceeded $30 \mathrm{C}$ for any mulch treatment (Fig. 2). Consequently, temperatures encountered by most tomato roots would be in the optimum range for all treatments after canopy closure and would not be expected to influence tomato growth during the later portion of the season.

Tindall et al. (199 I) showed that soil temperatures at $5 \mathrm{~cm}$ deep under black polyethylene mulch averaged about 35C for most of the season and suggested that excessive soil temperatures contributed to inferior yield of tomatoes grown with black polyethylene than straw mulch. However, soil at $5 \mathrm{~cm}$ deep on the edge of the bed was the only area to experience soil temperatures elevated enough to limit root growth and function in our research (Tables 1 and 2). Roots in this area represented only a fraction of the total root length (Table 4), so excessive temperatures in this area probably were not limiting to overall tomato growth and reproduction. More research is needed to determine if exposure of part of a root system to excessive temperatures is sufficient to inhibit plant growth.

Total yield in the hairy vetch treatment did not reflect reduced early growth and early yield (Table 5). Despite cooler soils than the other treatments early in the season, tomato plants grown with a hairy vetch mulch produced equal or greater total yields than plants in the other treatments. These results confirm earlier research by Abdul-Baki and Teasdale (1993). Soil temperature modification by mulches explain early tomato growth and yield but not total yield. Soil temperatures after canopy closure did not deviate enough from the optimum range in any treatment to explain total yields. Factors other than soil temperature must be addressed to account for yield enhancement by hairy vetch.

\section{Literature Cited}

Abdul-Baki, A.A. and J.R. Teasdale. 1993. A no-tillage tomato production system using hairy vetch and subterranean clover mulches. HortScience 28:106-108.

Ashworth, S. and H. Harrison. 1983. Evaluation of mulches for use in the home garden. Ho\&Science 18:180-182.

Böhm, W. 1979. Methods of studying root systems. Springer-Verlag, Berlin. p. 134.

Bristow, K.L. 1988. The role of mulch and its architecture in modifying soil temperature. Austral. J. Soil Res. 26:269-280.

Ham, J.M., G.J. Kluitenberg, and W.J. Lamont. 1993. Optical properties of plastic mulches affect the field temperature regime. J. Amer. Soc. Hort. Sci. 118:188-193.

Hillel, D. 1982. Introduction to soil physics. Academic Press, New York.

Knavel, D.E. and H.C. Mohr. 1967. Distribution of roots of four different vegetables under paper and polyethylene mulches. J. Amer. Soc. Hort. Sci. 91:589-597.

Liakatas, A., J.A. Clark, and J.L. Monteith. 1986. Measurements of the heat balance under plastic mulches. Part I. Radiation balance and soil heat flux. Agr. For. Meteorol. 36:227-239.

Maletta, M. and H.W. Janes. 1987. Interrelation of root and shoot temperatures on dry matter accumulation and root growth in tomato seedlings. J. Hort. Sci. 62:49-54.

Teasdale, J.R. and C.S.T. Daughtry. 1993. Weed suppression by live and desiccated hairy vetch. Weed Sci. 41:207-212.

Teasdale, J.R. and CL. Mohler. 1993. Light transmittance, soil temperature, and soil moisture under residue of hairy vetch and rye. Agron. J. 85:673-680.

Tindall, J.A., H.A. Mills, and D.E. Radcliffe. 1990. The effect of root zone temperature on nutrient uptake of tomato. J. Plant Nutr. 13:939-956.

Tindall, J.A., R.B. Beverly, and D.E. Radcliffe. 1991. Mulch effect on soil properties and tomato growth using micro-irrigation. Agron. J. 83:10281034.

Weaver, J.E. and W.E. Bruner. 1927. Root development of vegetable crops. McGraw-Hill, New York.

Wien, H.C., P.L. Minotti, and V.P. Grubinger. 1993. Polyethylene mulch stimulates early root growth and nutrient uptake of transplanted tomatoes. J. Amer. Soc. Hort. Sci. 118:207-211.

Table 5. Relationship between soil temperature $15 \mathrm{~cm}$ deep within the row and tomato growth. ${ }^{2 .}$

\begin{tabular}{|c|c|c|c|c|c|c|c|c|c|c|}
\hline \multirow[b]{2}{*}{ Year } & \multirow[b]{2}{*}{ Mulch } & \multicolumn{4}{|c|}{$\begin{array}{c}\text { No. of } h / \text { day at a } \\
\text { soil temp of } 20-30 \mathrm{C}\end{array}$} & \multirow{2}{*}{$\begin{array}{l}\text { Early root } \\
\text { length } \\
\left(\mathrm{cm} \cdot \mathrm{dm}^{-3}\right)\end{array}$} & \multirow{2}{*}{$\begin{array}{c}\text { Early leaf } \\
\text { area/plant } \\
\left(\mathrm{dm}^{2}\right)\end{array}$} & \multirow{2}{*}{$\begin{array}{l}\text { Early dry } \\
\text { wt/plant } \\
\text { (g) }\end{array}$} & \multirow{2}{*}{$\begin{array}{c}\text { Early } \\
\text { yield } \\
\left(\mathrm{Mg} \cdot \mathrm{ha}^{-1}\right)\end{array}$} & \multirow{2}{*}{$\begin{array}{c}\text { Total } \\
\text { yield } \\
\left(\mathbf{M g} \cdot \mathbf{h a}^{-1}\right)\end{array}$} \\
\hline & & Week 1 & Week 2 & Week 3 & Week 4 & & & & & \\
\hline \multirow[t]{3}{*}{$\overline{1992}$} & Black polyethelene & $8.2 \mathrm{a}$ & $10.4 \mathrm{a}$ & $8.4 \mathrm{a}$ & $18.2 \mathrm{a}$ & --- & $20.1 \mathrm{a}$ & $14.8 \mathrm{a}$ & $9.85 \mathrm{a}$ & $46.3 \mathrm{~b}$ \\
\hline & None & $4.2 \mathrm{~b}$ & $6.4 \mathrm{~b}$ & $3.4 \mathrm{~b}$ & $15.0 \mathrm{~b}$ & --- & $5.3 \mathrm{~b}$ & $5.4 \mathrm{~b}$ & $4.00 \mathrm{~b}$ & $33.7 \mathrm{~b}$ \\
\hline & Hairy vetch & $1.5 \mathrm{c}$ & $4.6 \mathrm{c}$ & $1.7 \mathrm{c}$ & $14.4 \mathrm{c}$ & --- & $10.0 \mathrm{~b}$ & $8.2 \mathrm{~b}$ & $1.72 \mathrm{~b}$ & $91.6 \mathrm{a}$ \\
\hline \multirow[t]{3}{*}{1993} & Black polyethelene & --- & $13.7 \mathrm{a}$ & $23.0 \mathrm{a}$ & $20.4 \mathrm{a}$ & 245 a & $168 \mathrm{a}$ & $167 \mathrm{a}$ & $14.9 \mathrm{a}$ & $88.0 \mathrm{ab}$ \\
\hline & None & $\ldots$ & $5.5 \mathrm{~b}$ & $17.8 \mathrm{~b}$ & $12.3 \mathrm{~b}$ & $203 \mathrm{~b}$ & $127 \mathrm{a}$ & $125 \mathrm{~b}$ & $10.0 \mathrm{~b}$ & $77.4 \mathrm{~b}$ \\
\hline & Hairy vetch & --- & $4.4 \mathrm{c}$ & $14.4 \mathrm{c}$ & $13.4 \mathrm{~b}$ & $180 \mathrm{~b}$ & $141 \mathrm{a}$ & $131 \mathrm{~b}$ & $7.3 \mathrm{c}$ & $95.8 \mathrm{a}$ \\
\hline
\end{tabular}

$\overline{\overline{2}}$ Values within columns followed by the same letter are not significantly different according the Fisher's LSD $(\mathrm{P}=0.05)$.

'Root, leaf area, and biomass samples taken during week 41992 and week 61993. 